\title{
The Mediating Effects of Organizational Commitment on the Relationship between Transformational Leadership Style and Job Performance
}

\author{
Dhaifallah Obaid Almutairi ${ }^{1}$ \\ ${ }^{1}$ King Abdulaziz Military Academy, Kingdom of Saudi Arabia \\ Correspondence: Dhaifallah Obaid Almutairi, King Abdulaziz Military Academy, Kingdom of Saudi Arabia. \\ E-mail: dalmutairi2002@yahoo.com
}

Received: October 19, 2015

Accepted: November 18, 2015

Online Published: December 18, 2015

doi:10.5539/ijbm.v11n1p231

URL: http://dx.doi.org/10.5539/ijbm.v11n1p231

\begin{abstract}
Nurses are considered the most valuable assets in hospitals, and leadership style is one of the determinants that can affect their performance. The purpose of this study is to examine the mediating effects of organizational commitment on the relationship between transformational leadership style and employees' job performance among Saudi female nurses. Four hospitals located in Riyadh and 227 Saudi female nurses were selected for this study. The results indicate that transformational leadership style is positively correlated with job performance and affective organizational commitment. The findings also reveal that affective organizational commitment mediates the relationship between transformational leadership style and job performance. This study recommends that hospital management should provide the groundwork for instilling transformational leadership styles and mangers should pay more attention to their leadership style in order to enhance job performance. This study also suggests further research that would include different measures and a larger sample as well as other areas, which could result in better understanding of the relationship between the variables.
\end{abstract}

Keywords: transformational leadership style, job performance, affective organizational commitment, hospitals in Saudi Arabia

\section{Introduction}

In today's competitive and changing environment, organizations experience numerous challenges in achieving their goals. Organizations that work in knowledge-based environments face pressure from customers to provide services of good quality. However, increasing employee performance will positively influence the organization's performance and ultimately, the quality of services. It has been asserted that organizational performance and effectiveness can be enhanced through commitment and organizational culture (Deal \& Kennedy, 2000). Moreover, the performance of the entire organization is very tightly linked to each individual's performance (Fontannaz \& Oosthuizen, 2007). Besides, organizational commitment can enhance employee performance. Several researchers have proven that committed employees perform better (Mathieu \& Zajac, 1990; Guest, 1997; Suliman \& Iles, 2000; Liou, 2008). It has additionally been reported that increasing organizational commitment leads to decreasing workforce turnover (Porter et al., 1974; Wasti, 2003) and consequently, increasing employee performance (Jaramillo et al., 2005). Furthermore, the higher the level of employee performance, the better the overall organizational effectiveness will be (Cummings \& Schwab, 1973).

Considering the fact that organizations' success depends on employees' performance, another main factor in organizational success is leadership style. It is the ability of leaders to affect their followers by making them more satisfied and committed, which in turn augments outcome (Mosadeghard, 2003). The empirical results from the majority of recent research studies indicate that employee performance, job satisfaction as well as affective commitment are outcomes highly desired by leaders (Dionne et al., 2004; Bass \& Riggio, 2006). A large number of researchers have suggested that leaders can motivate and help their employees succeed in today's globally competitive environment with effective leadership styles (Bass \& Riggio, 2006). It is argued that effective leadership has a positive effect on organizational performance (Bass \& Avolio, 1997).

Although leadership style and job performance have been studied extensively, little is known about the mediating role of organizational commitment on the relationship between leadership style and job performance 
(Yousef, 2000; Yeh \& Chien, 2012). Therefore, this study is an addition to the limited existing literature on leadership, job performance and organizational commitment, particularly in Saudi Arabia. The objective of this study is to investigate the mediating effects of organizational commitment on the relationship between leadership style and job performance among Saudi female nurses. The findings of this study should help leaders better understand the effects of their leadership style on employee and organization performance as a whole, as well as the role of organizational commitment. This study is divided into five sections. Section one presented an introduction, section two addresses a literature review, section three contains the research methodology, section four presents the results and discussion, and section five concludes the study.

\section{Literature Review}

\subsection{Leadership}

The constant changes in organizational life highlight the increasing importance of leadership. As such, leadership is one of the most studied topics worldwide (Kuchler, 2008). Leadership can be described as an interaction process between leaders and their employees, whereby leaders attempt to influence employees to fulfill common goals (Yukl, 2005; Northouse, 2010). Leadership style is the manner and approach of motivating people, providing direction and achieving goals (Amirul \& Daud, 2012). Style can either encourage or discourage empolyees, which can in turn lead to increasing or decreasing performance levels (Belonio, 2012). However, leadership has been of interest to many researchers, who have proposed numerous leadership theories and models. According to Doyle and Smith (1999), leadership theories can be divided into four categories: trait, behavioral, contingency, and the transformational and transactional theories.

Unlike the early leadership theories that focus on effective and successful leader characteristics such as traits, behaviour and contingency, transformational leadership has shifted emphasis from the traditional or transactional model toward the study of transformational leadership. Transformational leadership occurs when a leader raises the level of awareness about the value of desired results and expands subordinates' wants and needs (Bass, 1985). According to Schepers et al. (2005), transformational leaders allow subordinates to think creatively, analyse problems from different angles and provide better solutions by using technology. Gill et al. (2006) claimed that organizations can reduce job stress and burnout by adopting a transformational leadership style. Many studies have signified that transformational leadership has positive effects on followers' efforts and satisfaction (Bycio et al., 1995; Kirkpatrick \& Locke, 1996; Parry, 2000). Compared with other styles, transformational leadership is deemed advantageous in developing leaders and enhancing subordinates' loyalty, trust and self-esteem (Barling et al., 1996; Northouse, 2009). Therefore, transformational leadership is the most effective form of leadership, where the leaders are closely engaged with, and motivate their subordinates to achieve beyond their transactional agreements (Panagopoulous \& Dimitriadis, 2009).

According to Mosadeghard (2003), there are several leadership styles, including autocratic, bureaucratic, laissez-faire, democratic, participative, situational, transactional and transformational. However, if leaders wish to produce positive effects on employees and organizations, then leadership should be shifted from the traditional autocratic style to more sociable styles (Dess et al., 1998). Effective leaders adopt styles that support employees, provide them with a vision, instill hope and motivate them to think innovatively. All these features are observed in transformational leadership. Moreover, the transformational style functions better than other styles in terms of employees retaining their jobs besides having job satisfaction (Fletcher, 2001; Dvir et al., 2002; Berggren \& Severinsson, 2003). This type of leadership is more motivational in contrast with other styles (Kirkman et al., 2009). In the current study, transformational leadership will be discussed.

\subsection{Job Performance}

Job performance is one of the most notable indicators in evaluating organizational performance (Wall et al., 2004). Schermerhorn (1989) described job performance as quality and quantity achieved by individuals or groups upon fulfilling a task. Munchinsky (2003) proposed that job performance is a set of employee behaviors that can be measured, monitored and evaluated in terms of achievement at the individual level. According to Schermerhorn (1989), job performance is the result of quality and quantity once employees complete a mission. Due to its importance, several studies have been conducted to explore ways of enhancing empolyee performance (Park et al., 2003; Tessema \& Soeters, 2006; Kahya, 2009). Nurses' performance can be described as the duties performed by nurses. Acording to Amos et al. (2004), the effective management of individual performance is essential to the implementation of organizational strategies. 


\subsection{Organizational Commitment}

Organizational commitment is among the most popular topics in the field of management research (Wasti, 2003). Organizational commitment is vital to any organization, because it is a good predictor of organizational goals, absenteeism, turnover and productivity (Bushra et al., 2011). It has been defined in a variety of ways by different researchers. Luthans (2005) defined organizational commitment as an attitude reflecting workers' loyalty to their organization. Henkin and Marchiori (2003) described it as a sentiment that drives workers to be part of an organization and to recognize the organization's goals and values.

A according to Mowday et al. (1979), organizational commitment includes three elements: a strong belief in, and acceptance of the organization's goals and values, willingness to exert considerable effort on behalf of the organization, and a strong desire to maintain organizational position. Mayer and Allen (1991) also classified organizational commitment into three components: affective commitment, continuous commitment and normative commitment. According to Mayer and Allen (1991), affective commitment refers to employees' emotional attachment to the organization, including beliefs and desires regarding organizational goal achievements. Continuous commitment refers to employees' feelings of obligation to remain with the organization. Finally, normative commitment is based on the cost incurred by employees if they wish to leave the organization. However, affective commitment is more important for employees. It is also viewed as extremely beneficial to organizations (Meyer \& Allen, 1997). Furthermore, affective commitment has received the most attention in research (Mathieu \& Zajac, 1990; Meyer et al., 2002). According to Meyer and Allen (1997), affectively committed employees are likely to possess a set of positive reactions and behaviours in the workplace, as well as a willingness to contribute to the organization's purpose. In this study, organizational commitment refers to affective commitment.

\subsection{Transformational Leadership Style, Job Performance and Organizational Commitment}

Leadership is vital to determining employees' commitment. Researchers have observed that employees who are pleased with their managers feel more attachment to their organizations (Stup, 2006). Leaders can lead individuals or groups to attain goals and develop employees' commitment to the organization. Therefore, leadership style is considered a critical factor that influences organizational commitment. According to Ramachandran and Krishnan (2009), leadership style is among the most significant determinants of employee commitment. Organizational commitment indicates that individual goals are similar or identical to the organizational goals and they motivate employee productivity and loyalty (Chen \& Aryee, 2007). Hence, organizational commitment can enhance employee performance.

Leadership may affect employees' behaviour, satisfaction and performance, which can subsequently affect the level of organizational commitment (Bass, 1985). However, the majority of studies associate the transformational leadership style with employee job performance (Raja \& Palanichamy, 2011). Deluga and Souza (2011) discovered that performance and transformational leadership style are correlated. In a study conducted by Howell et al. (2005), a positive relationship was found between transformational leadership and employee job performance. Findings by Dvir et al. (2002) revealed that employee job performance is facilitated by transformational leadership. Geyery and Steyrer (1998) found that there is a positive relationship between transformational leadership and job performance. Thamrin (2012) asserted that transformational leadership style has a positive and significant effect on employees' job performance and organizational commitment.

Researchers have also conducted various studies to examine the effects of organizational commitment on job performance. Morris and Sherman (1981) indicated that organizational commitment is effective in predicting job performance. Meyer et al. (1989) found that organizational commitment is a suitable indicator of job performance. Other studies have additionally shown a positive relationship between organizational commitment and job performance (Benkhoff, 1997; Suliman \& Iles, 2000; Meyer et al., 2002; Chi et al., 2007).

Some studies have indicated a positive relationship between transformational leadership style and organizational commitment. Lee (2010) observed that transformational leadership style has a positive and significant effect on organizational commitment. Barbuto (2005) presented similar findings, while Mert et al. (2010) also discovered a significant relationship between transformational leadership style and organizational commitment. Ying and Ahmad (2009) suggested that leadership style influences organizational commitment and in turn, organizational commitment affects employees' job performance and mediates the relationship between leadership style and job performance. According to Wang (2006), leadership style and organizational commitment positively affect employees' performance. Yeh and Hong (2012) found that organizational commitment partially mediates the relationship between leadership style and job performance. In a study conducted by Chi et al. (2007), the results signified that organizational commitment fully mediates the relationship between leadership style and job 
performance. Wells and Peachey (2011) used job satisfaction as a mediator between leadership style and turnover intention, and recommended organizational commitment as a mediating variable to be applied in future studies. In addition, organizational commitment serves as a mediator in various other studies (Udo et al., 1997; Clugston, 2000; Suliman, 2002).

Based on the above literature review, this study is designed to test the following hypotheses:

H1: There is a significant relationship between transformational leadership style and job performance.

$\mathrm{H} 2$ : There is a significant relationship between transformational leadership style and affective organizational commitment.

H3: There is a significant relationship between affective organizational commitment and job performance.

H4: Affective organizational commitment mediates the relationship between transformational leadership style and job performance.

\section{Research Methodology}

\subsection{Research Design and Sample}

A descriptive and correlational research design is applied in this study to collect data using a questionnaire. The population for this study includes Saudi female nurses at 4 large government hospitals in Riyadh, namely King Fahad National Guard Hospital, Shimasy Hospital, Yamama Hospital, and Military Hospital. A questionnaire was the tool employed for data collection. The sampling procedure used was the simple random sampling technique. 270 questionnaires were distributed in these four locations (hospitals), 241 questionnaires were returned, and out of 241 returned questionnaires, 14 were excluded due to invalid responses. The final sample comprised 227 , signifying a response rate of $84 \%$.

\subsection{Measurements}

In this study, the Multifactor Leadership Questionnaire (MLQ) developed by Bass \& Avolio (1995) was used to measure transformational leadership style (independent variable). The questionnaire contained 20 items that were evaluated on a 5 -point Likert scale with $1=$ not at all, $2=$ once in a while, $3=$ sometimes, $4=$ fairly often and $5=$ frequently, if not always. To investigate job performance (dependent variable), 4 items were evaluated using a 5-point Likert scale ranging from "1" (very low) to "5"(very high), which was designed by Stevens et al. (1978). The first two items refer to quality and productivity, and the other two items evaluate employees' performance compared with similar peers' jobs.

To evaluate affective organizational commitment (mediating variable), the questionnaire developed by Meyer, Allen, and Smith (1993) and Meyer and Allen (1997) was adopted in this study. The questionnaire consists of 18 items measuring components of organizational commitment (6 items for each scale). As this study focuses on affective organizational commitment, 6 items relating to this dimension were used. Respondents answered on a 5 -point Likert scale $(1=$ strongly disagree, $2=$ disagree, $3=$ neither agree nor disagree, $4=$ agree, $5=$ strongly agree). However, this section of the questionnaire contains several reverse statements. According to Dillman (2007), it is recommended for the scalar answer categories to have a consistent direction throughout the entire instrument. Therefore, these items were all positively worded. For example, "I do not feel like 'part of the family' in my organization" has been modified to "I feel like "part of the family' in my organization".

The instrument reliability was tested with Cronbach's alpha. Nunnally (1978) stated that reliability with less than 0.6 is considered poor, in the 0.7 range it is acceptable, while values above 0.8 are good. All instruments showed an acceptable level of reliability (Nunnally, 1978). The transformational leadership style had a Cronbach's alpha value of 0.84 , job performance 0.76 and affective organizational commitment 0.73 . Descriptive statistics in terms of frequency and percentage served to describe respondents' characteristics such as age and number of years in service.

Pearson's correlation coefficient was used to determine the relationship between variables (transformational leadership style, job performance and affective organizational commitment). According to Sekaran (2003), the correlation between two variables is considered a perfect positive correlation when it is close to +1 or perfect negative correlation when it is close to -1 . In order to test the mediating effects, a three-step regression suggested by Baron and Kenny (1986) was used. The three steps are: (1) the independent variable affects the mediating variable; (2) the independent variable affects the dependent variable; and (3) after including the mediating variable into the second regression equation of the previous step, the relationship between independent and dependent variables is significantly diminished. In other words, a full mediating effect holds if the relationship between the independent and dependent variables controlling the mediator is zero. Partial mediation holds when 
the relationship between the independent and dependent variables is significant and smaller when the mediator is in the equation than when the mediator is not. However, according to Baron and Kenny (1986), hierarchical or stepwise regression, or computing any partial or semi partial correlation are not necessary.

\section{Data analysis and Results}

\subsection{Sample Characteristics}

As tabulated in Table 1, the total number of nurses who participated in this study was 227 . The demographic data revealed that $21.1 \%$ of the respondents were aged between 20 and 26 years, $37.4 \%$ were between 27 and 33 years old, $22.9 \%$ were between 34 and 40 years old, $9.7 \%$ were between 41 and $47,4.8 \%$ were aged between 48 and 54 , and $4 \%$ were above 54 years old. In terms of the number of years in service, $37.4 \%$ of nurses had between 1 and 5 years of experience, $32.2 \%$ had between 6 and 10 years of experience, $16.3 \%$ had between 11 and 15 years, $8.8 \%$ had between 16 and 20 years, and $5.3 \%$ of nurses had more than 20 years of experience.

Table 1. Respondents' demographic data

\begin{tabular}{lll}
\hline Variable & Frequency & Percentage \\
\hline Age: $20-26$ years & 48 & $21.1 \%$ \\
Age: $27-33$ years & 85 & $37.4 \%$ \\
Age: $34-40$ years & 52 & $22.9 \%$ \\
Age: $41-47$ years & 22 & $9.7 \%$ \\
Age: $48-54$ years & 11 & $4.8 \%$ \\
Age: 54 years + & 9 & $4 \%$ \\
Experience: $\quad 1-5$ years & 71 & $37.4 \%$ \\
Experience: $\quad 6-10$ years & 58 & $32.2 \%$ \\
Experience: $\quad 11-15$ years & 42 & $16.3 \%$ \\
Experience: $\quad 16-20$ years & 16 & $8.8 \%$ \\
Experience: more than 20 years & 16 & $5.3 \%$ \\
\hline
\end{tabular}

\subsection{Correlation}

The relationship between variables was investigated using Pearson correlation. The results show there is a significant relationship between transformational leadership style and job performance $(r=0.894, p<0.01)$ and affective organizational commitment $(\mathrm{r}=.579, \mathrm{p}<0.01)$. In addition, there is a significant relationship between affective organizational commitment and job performance $(\mathrm{r}=.590, \mathrm{p}<0.01)$. Therefore, research hypotheses $\mathrm{H} 1, \mathrm{H} 2, \mathrm{H} 3$ are accepted and proven to be true. From this result, it can be concluded that transformational leadership style is positively related to both affective organizational commitment and job performance. Furthermore, affective organizational commitment is positively related to job performance. This implies that an increase in transformational leadership style practice will be followed by an increase in job performance and affective organizational commitment. An increase in affective organizational commitment level will also be followed by an increase in job performance. Table 2 below summarizes the results of the correlation between the study variables.

Table 2. Correlation between the study variables

\begin{tabular}{llll}
\hline & Transformational Leadership & Job Performance & Organizational Commitment \\
\cline { 2 - 4 } & Transformational leadership 1 & $1.894^{* *}$ & $.579^{* *}$ \\
Job performance & 1 & $.590^{* *}$ \\
Organizational commitment & & 1 \\
\hline **. Correlation is significant at the 0.01 level (2-tailed).
\end{tabular}

\subsection{Regression Analysis}

In order to test the mediation effects, the three-step regression procedure suggested by Baron and Kenny (1986) was followed to verify whether affective organizational commitment is a mediating variable in the relationship between transformational leadership style and job perfromance. According to Baron and Kenny, the existence of 
mediation effects is determined if the following conditions hold: (1) the independent variable (transformational leadership style) affects the mediating variable (affective organizational commitmet) in the first regression equation; (2) the independent variable (transformational leadership style) affects the dependent variable (job perfroamnce) in the second equation; and (3) after including the mediating variable (affective organizational commitment) into the second regression equation of the previous step, the relationship between the independent variable (transformational leadership style) and the dependent variable (job performance) is significantly lower and there is a significant relationship between the mediating variable (affective organizational commitment) and the dependent variable (job performance).

In terms of the mediation procedure (Table 3), step 1 indicates that transformational leadership style seems to influence affective organizational commitment $(\beta=0.579, \mathrm{P}<0.001)$. In step 2 , transformational leadership style appears to affect job performance $(\beta=0.894, \mathrm{P}<0.001)$. In step 3 , when affective organizational commitment (the mediator) is included in the above regression equation, affective organizational commitment has a positive and significant effect on job performance, and transformational leadership style still significantly affect job performance but the regression coefficient of transformational leadership style and job performance reduced from 0.894 to $0.832(\mathrm{p}<0.001)$. This reveals that affective organizational commitment partially mediates the relationship between leadership style and job performance. Hence, hypothesis 4 is supported. From this result it is derived that through the process of affective organizational commitment, transformational leadership style can enhance employees' job performance. Figure 1 illustrates the path analysis model of mediation.

Table 3. Regression analysis of affective organizational commitment mediating transformational leadership style and job performance

\begin{tabular}{llllll}
\hline Step & Independent variable & Dependent variable & $\beta$ & $\mathrm{R}^{2}$ & Adjusted $\mathrm{R}^{2}$ \\
\hline 1) & Transformational leadership style & Affective organizational commitment & $0.579^{* * *}$ & 0.336 & 0.333 \\
2) & Transformational leadership style & Job perfromance & $0.894^{* * *}$ & 0.800 & 0.799 \\
$3)$ & Transformational leadership style & Job perfromance & $0.832^{* * *}$ & 0.808 & 0.806 \\
& Affective organizational commitment & & $0.107^{* *}$ & & \\
\hline
\end{tabular}

Note. ${ }^{*} \mathrm{p}<0.05, * * \mathrm{p}<0.01, * * *<0,001$.

The regression coefficient in the table above is a standaraized coefficient.

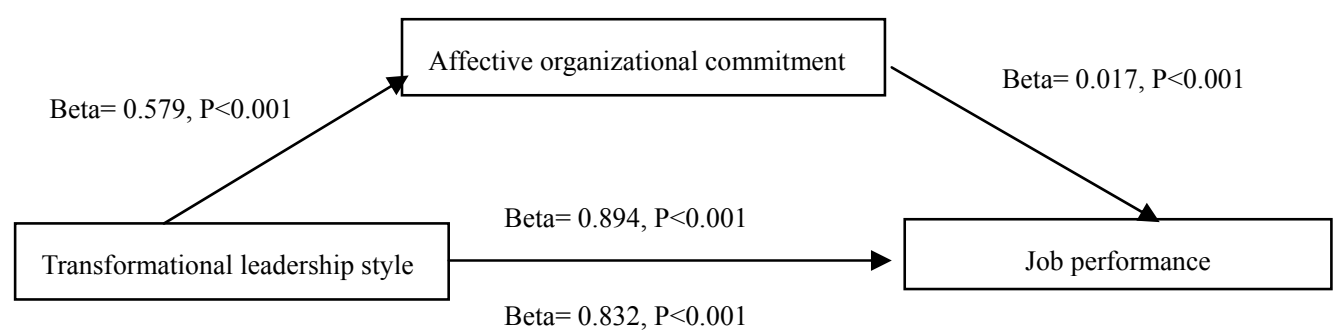

Figure 1. Path analysis model of mediation

\section{Discussion and Conclusions}

The purpose of this study was to examine the relationship between transformational leadership style and job performance among Saudi female nurses from 4 government hospitals in Riyadh, Saudi Arabia. The findings of the study reveal there is a significant, positive relationship between transformational leadership style and job performance. The current research findings are consistent with previous studies (Geyery \& Steyrer, 1998; Dvir et al., 2002; Howell et al., 2005; Deluga \& Souza, 2011; Thamrin, 2012). The present study results also indicate there is a significant positive relationship between affective organizational commitment and job performance among Saudi female nurses. These findings support earlier studies as well (Morris \& Sherman, 1981; Meyer et al., 1989; Benkhoff, 1997; Suliman \& Iles, 2000; Meyer et al., 2002; Chi et al., 2007). 
In addition, the present findings assert there is a positive relationship between transformational leadership style and affective organizational commitment. These results are in line with the past studies (Barbuto, 2005; Yiing \& Ahmad, 2009; Lee, 2010; Mert et al., 2010). In terms of the mediating effects of affective organizational commitment, the findings of this study indicate that affective organizational commitment partially mediates the relationship between transformational leadership and job performance. These findings are consistent with prior studies (Chi et al., 2007; Yeh \& Hong, 2012). Based on the results, the current study provides insight from a Saudi perspective and all findings on Saudi data are consistent with earlier literature.

The main contribution of this study is in determining that affective organizational commitment has a mediating effect on the transformational leadership style and job performance relationship. This demonstrates that transformational leadership style is an important variable in enhancing employees' commitment, which means employees working harder. Furthermore, the results of the current study suggest that transformational leadership style is a positive predictor of affective organizational commitment and job performance. It is believed this study will help managers in the health sector. Based on the findings, managers ought to pay more attention to their leadership style and adopt a transformational leadership style as a way to boost employees' commitment and performance levels. In addition, the study outcomes may help hospital managers understand that employees' performance is not only influenced and improved by a transformational leadership style but it can also be enhanced through the high organizational commitment of employees.

Considering the importance of job performance and affective organizational commitment in hospitals, it is recommended for hospital management to provide the groundwork for implementing a transformational leadership style. Thus, both the affective organizational commitment and job performance of female nurses would enhance. Although this study does contribute to the limited body of knowledge to date on transformational leadership style, job performance and affective organizational commitment in Saudi Arabia, there are still, of course, a number of limitations. First, the transformational leadership style was selected for this study, but other styles such as transactional and laissez-faire should be considered in future studies. Second, data were collected via questionnaire, which may not capture completely true participant responses. In addition, this study was conducted in Riyadh only, despite Saudi Arabia having several areas and cities where traditions slightly vary. In order to overcome these limitations, further studies are needed to investigate the link between these variables using different measures such as interviews and including larger samples from different regions of Saudi Arabia.

\section{Acknowledgements}

The author gratefully acknowledges the managers and nurses for their assistance in conducting this study.

\section{References}

Amirul, S. R., \& Daud, N. (2012). A study on the relationship between leadership styles and leadership effectiveness in Malaysian GLCs. European Journal of Business and Management, 4(8), 193-201.

Amos, T. L., Ristow, A., \& Ristow, L. (2004). Human Resource Management (2nd ed.). Lansdowne: Juta and CoLtd.

Barbuto, J. E. (2005). Motivation and transactional, charismatic, and transformational leadership: A test of antecedents. Journal of Leadership \& Organizational Studies, 11(4), 26-40. http://dx.doi.org/10.1177/107179190501100403

Barling, J., Weber, T., \& Kelloway, E. K. (1996). Effects of transformational leadership training on attitudinal and financial outcomes: A field experiment. Journal of Applied Psychology, 81(6), 827. http://dx.doi.org/10.1037/0021-9010.81.6.827

Baron, R. M., \& Kenny, D. A. (1986). The moderator-mediator variable distinction in social psychological research: Conceptual, strategic, and statistical considerations. Journal of Personality and Social Psychology, 51(6), 1173-1182. http://dx.doi.org/10.1037/0022-3514.51.6.1173

Bass, B. M. (1985). Leadership and performance beyond expectations. New York: Free Press.

Bass, B. M., \& Avolio, B. J. (1995). Manual for the multifactor leadership questionnaire: Rater form (5X short). Palo Alto, CA: Mind Garden.

Bass, B. M., \& Avolio, B. J. (1997). The Full Range Leadership Development Manual for the Multifactor Leadership Questionnaire. Redwood City, CA: Mind garden.

Bass, B. M., \& Riggio, R. E. (2006). Transformational leadership. Lawrence Erlbaum.

Belonio, R. (2012). The Effect of Leadership Style on Employee Job satisfaction and Performance of Bank 
Employee in Bankgkok. AU-GSB-e-Journal., 5(2), 111-116.

Benkhoff, B. (1997). Ignoring commitment is costly: New approaches establish the missing link between commitment and performance. Human Relations, 50(6), 701-726. http://dx.doi.org/10.1177/001872679705000604

Berggren, I., \& Severinsson, E. (2003). Nurse supervisors' actions in relation to their decision-making style and ethical approach to clinical supervision. Journal of Advanced Nursing, 41(6), 615-622. http://dx.doi.org/10.1046/j.1365-2648.2003.02573.x

Bushra, F., Usman, A., \& Naveed, A. (2011). Effect of Transformational Leadership on Employees' Job Satisfaction and Organizational Commitment in Banking Sector of Lahore (Pakistan). International Journal of Business and Social Science, 2(18), 261-267.

Bycio, P., Hackett, R. D., \& Allen, J. S. (1995). Further assessments of Bass's (1985) conceptualization of transactional and transformational leadership. Journal of Applied Psychology, 80(4), 468-478. http://dx.doi.org/10.1037/0021-9010.80.4.468

Chen, Z. X., \& Aryee, S. (2007). Delegation and employee work outcomes: An examination of the cultural context of mediating processes in China. Academy of Management Journal, 50(1), 226-238. http://dx.doi.org/10.5465/AMJ.2007.24162389

Chi, H., Tsai, H., \& Chang, P. (2007). Investigating the relationship among leadership styles, emotional intelligence and organization commitment on job performance: A study of salespeople in Thailand. The Journal of Human Resource and Adult Learning, 3(2), 199-212.

Clugston, M. (2000). The mediating effects of multidimensional commitment on job satisfaction and intent to leave. Journal of Organizational Behavior, 21(4), 477-486. http://dx.doi.org/10.1002/(SICI)1099-1379(200006)21:4<477::AID-JOB25>3.0.CO;2-7

Cummings, L., \& Schwab, D. (1973). Performance in organizations: Determinants and appraisal. Scott Foresman. Glenview, Illinois.

Deal, T. E., \& Kennedy, A. A. (2000). Corporate cultures: The rites and rituals of corporate life: Basic Books.

Deluga, R. J., \& Souza, J. (2011). The effects of transformational and transactional leadership styles on the influencing behaviour of subordinate police officers. Journal of Occupational Psychology, 64(1), 49-55. http://dx.doi.org/10.1111/j.2044-8325.1991.tb00540.x

Dess, G. G., Picken, J. C., \& lyon, D. W. (1998). Transformational Leadership. Journal of Managerial Issues, 10, $30-44$.

Dillman, D. A. (2007). Mail and internet surveys: The tailored design method (2nd ed.). Hoboken, NJ: John Wiley \& Sons, Inc.

Dionne, S. D., Yammarino, F. J., Atwater, L. E., \& Spangler, W. D. (2004). Transformational leadership and team performance. Journal of Organizational Change Management, 17(2), 177-193. http://dx.doi.org/10.1108/09534810410530601

Doyle, M. E., \& Smith, M. (1999). Born and bred?: Leadership, heart and informal education. London: YMCA George Williams College.

Dvir, T., Eden, D., Avolio, B. J., \& Shamir, B. (2002). Impact of transformational leadership on follower development and performance. Academy of Management Journal, 45(4), 735-744. http://dx.doi.org/10.2307/3069307

Fletcher, C. E. (2001). Hospital RNs' job satisfactions and dissatisfactions. Journal of Nursing Administration, 31(6), 324. http://dx.doi.org/10.1097/00005110-200106000-00011

Fontannaz, S., \& Oosthuizen, H. (2007). The development of a conceptual framework to guide sustainable job performance. South African Journal of Business Management, 38(4), 9-19.

Geyery, A. L. J., \& Steyrer, J. M. (1998). Transformational leadership and objective performance in banks. Applied Psychology, 47(3), 397-420. http://dx.doi.org/10.1111/j.1464-0597.1998.tb00035.x

Gill, A. S., Flaschner, A. B., \& Shachar, M. (2006). Mitigating stress and burnout by implementing transformational-leadership. International Journal of Contemporary Hospitality Management, 18(6), 469-481. http://dx.doi.org/10.1108/09596110610681511

Guest, D. E. (1997). Human resource management and performance: A review and research agenda. 
International Journal of Human Resource Management, $\quad$ 8(3), 263-276. http://dx.doi.org/10.1080/095851997341630

Henkin, A. B., \& Marchiori, D. M. (2003). Empowerment and organizational commitment of chiropractic faculty. Journal of Manipulative and Physiological Therapeutics, 26(5), 275-281. http://dx.doi.org/10.1016/S0161-4754(03)00043-5

Howell, J. M., Neufeld, D. J., \& Avolio, B. J. (2005). Examining the relationship of leadership and physical distance with business unit performance. The Leadership Quarterly, 16(2), $273-285$. http://dx.doi.org/10.1016/j.leaqua.2005.01.004

Jaramillo, F., Mulki, J. P., \& Marshall, G. W. (2005). A meta-analysis of the relationship between organizational commitment and salesperson job performance: 25 years of research. Journal of Business Research, 58(6), 705-714. http://dx.doi.org/10.1016/j.jbusres.2003.10.004

Kahya, E. (2009). The effects of job performance on effectiveness. International Journal of Industrial Ergonomics, 39(1), 96-104. http://dx.doi.org/10.1016/j.ergon.2008.06.006

Kirkman, B. L., Chen, G., Farh, J. L., Chen, Z. X., \& Lowe, K. B. (2009). Individual power distance orientation and follower reactions to transformational leaders: A cross-level, cross-cultural examination. The Academy of Management Journal ARCHIVE, 52(4), 744-764. http://dx.doi.org/10.5465/AMJ.2009.43669971

Kirkpatrick, S. A., \& Locke, E. A. (1996). Direct and indirect effects of three core charismatic leadership components on performance and attitudes. Journal of Applied Psychology, 81(1), 36. http://dx.doi.org/10.1037/0021-9010.81.1.36

Kuchler, W. J. (2008). Perceived leadership behavior and subordinates' job satisfaction in Midwestern NCAA Division III athletic departments. The Sport Journal, 11(2), 23-35.

Lee, H. W. (2010). Relationship between leadership style and organizational commitment. Operating Management Review, 6(1), 87-95.

Liou, S. (2008). An analysis of the concept of organizational commitment. Nursing Fórum, 43(3), $116-125$. http://dx.doi.org/10.1111/j.1744-6198.2008.00103.x

luthans, F. (2005). Organizational Behavior (10th ed.). New York: McGraw-Hill.

Mathieu, J. E., \& Zajac, D. M. (1990). A review and meta-analysis of the antecedents, correlates, and consequences of organizational commitment. Psychological Bulletin, 108(2), 171-194. http://dx.doi.org/10.1037/0033-2909.108.2.171

Mert, I. S., Keskin, N., \& Baş, T. (2010). Leadership style and organizational commitment: Test of a theory in Turkish banking sector. Journal of Academic Research in Economics, 2(1), 1-20.

Meyer, J. P., \& Allen, N. J. (1991). A three-component conceptualization of organizational commitment. Human Resource Management Review, 1(1), 61-89. http://dx.doi.org/10.1016/1053-4822(91)90011-Z

Meyer, J. P., \& Allen, N. J. (1997). Commitment in the workplace: Theory, research, and application. Thousand Oaks, CA.: Sage publications, inc.

Meyer, J. P., Allen, N. J., \& Smith, C. A. (1993). Commitment to organizations and occupations: Extension and test of a three-component conceptualization. Journal of Applied Psychology, 78(4), 538-551. http://dx.doi.org/10.1037/0021-9010.78.4.538

Meyer, J. P., Paunonen, S. V., Gellatly, I. R., Goffin, R. D., \& Jackson, D. N. (1989). Organizational commitment and job performance: It's the nature of the commitment that counts. Journal of Applied Psychology, 74(1), 152-156. http://dx.doi.org/10.1037/0021-9010.74.1.152

Meyer, J. P., Stanley, D. J., Herscovitch, L., \& Topolnytsky, L. (2002). Affective, continuance, and normative commitment to the organization: A meta-analysis of antecedents, correlates, and consequences. Journal of Vocational Behavior, 61(1), 20-52. http://dx.doi.org/10.1006/jvbe.2001.1842

Morris, J. H., \& Sherman, J. D. (1981). Generalizability of an organizational commitment model. Academy of Management Journal, 24(3), 512-526. http://dx.doi.org/10.2307/255572

Mosadeghard, A. M. (2003). The Role of Participative Management (Suggestion System) in Hospital Effectiveness and Efficiency. Research in Medical Sciences, 8(3), 85-89.

Mosadeghrad, A. M. (2003). Principles of Health Care Administration. Tehran: Dibagran Terhran. 
Mowday, R. T., Steers, R. M., \& Porter, L. W. (1979). The measurement of organizational commitment. Journal of Vocational Behavior, 14(2), 224-247. http://dx.doi.org/10.1016/0001-8791(79)90072-1

Muchinsky, P. M. (2003). Psychology Applied to Work. (7th ed. ed.). Belmont, CA:: Wadsworth.

Northouse, P. G. (2009). Leadership: Theory and practice (5th ed.). California: Sage Publications, Inc.

Northouse, P. G. (2010). Leadership, theory and practice (5th ed.). Thousand Oaks, CA: Sage.

Nunnally, J. C. (1978). Psychometric theory. New York: McGraw-Hill.

Panagopoulous, N., \& Dimitriadis, S. (2009). Transformational Leadership as a Mediator of the Relationship between Behavior-based Control and Salespeople's Key Outcomes. European Journal of Marketing, 43(7), 1008-1031.

Park, H. J., Mitsuhashi, H., Fey, C. F., \& Björkman, I. (2003). The effect of human resource management practices on Japanese MNC subsidiary performance: A partial mediating model. The International Journal of Human Resource Management, 14(8), 1391-1406. http://dx.doi.org/10.1080/0958519032000145819

Parry, K. (2000). Does leadership help the bottom line? Management-Auckland, 47(3), 38-41.

Porter, L., Steers, R., Mowday, R., \& Boulian, P. (1974). Organizational commitment, job satisfaction, and turnover among psychiatric technicians. Journal of Applied Psychology, 59(5), 603-609. http://dx.doi.org/10.1037/h0037335

Raja, A. S., \& Palanichamy, P. (2011). Leadership styles and its impact onoganizational commitment. The Journal of Commerce, 3(4), 17-18.

Ramachandran, S., \& Krishnan, V. (2009). Effect of transformational leadership on followers' affective and normative commitment: Culture as moderator. Great Lakes Herald, 3(1), 23-38.

Schepers, J., Wetzels, M., \& de Ruyter, K. (2005). Leadership styles in technology acceptance: Do followers practice what leaders preach? Managing Service Quality, 15(6), 496-508. http://dx.doi.org/10.1108/09604520510633998

Schermerhorn, J. R. (1989). Mnagement for productivity (3rd ed.). New York: John Wiley and Sons.

Sekaran, U. (2003). Research methods for business: A skill building approach (4th ed.). New Jersey: John Willey $\&$ Sons.

Stevens, J. M., Beyer, J. M., \& Trice, H. M. (1978). Assessing personal, role, and organizational predictors of managerial commitment. Academy of Management Journal, 21(3), 380-396. http://dx.doi.org/10.2307/255721

Stup, R. E. (2006). Human resource management and dairy employee organizational commitment: Pennsylvania State University.

Suliman, A. (2002). Is it really a mediating construct?: The mediating role of organizational commitment in work climate-performance relationship. Journal of Management Development, 21(3), 170-183. http://dx.doi.org/10.1108/02621710210420255

Suliman, A., \& Iles, P. (2000). Is continuance commitment beneficial to organizations? Commitment-performance relationship: A new look. Journal of Managerial Psychology, 15(5), 407-422. http://dx.doi.org/10.1108/02683940010337158

Tessema, M. T., \& Soeters, J. L. (2006). Challenges and prospects of HRM in developing countries: Testing the HRM-performance link in the Eritrean civil service. The International Journal of Human Resource Management, 17(1), 86-105. http://dx.doi.org/10.1080/09585190500366532

Thamrin, H. M. (2012). The influence of transformational leadership and organizational commitment on job satisfaction and employee performance. International Journal of Innovation, Management and Technology, $3(5), 566-572$.

Udo, G. J., Guimaraes, T., \& Igbaria, M. (1997). An investigation of the antecedents of turnover intention for manufacturing plant managers. International Journal of Operations \& Production Management, 17(9), 912-930. http://dx.doi.org/10.1108/01443579710171280

Wall, T. D., Michie, J., Patterson, M., Wood, S. J., Sheehan, M., \& Clegg, C. W. et al. (2004). On the validity of subjective measures of company performance. Personnel Psychology, 57(1), 95-118. http://dx.doi.org/10.1111/j.1744-6570.2004.tb02485.x 
Wang, C. (2006). Applying structural equation modeling to study the influence of leadership styles, job satisfaction, organization commitment and job performance: An empirical study of real estate agents in Taoyuan area. Unpublished master's thesis, National Donghwa University, Taiwan.

Wasti, S. A. (2003). Organizational commitment, turnover intentions and the influence of cultural values. Journal of Occupational and Organizational Psychology, 76(3), 303-321. http://dx.doi.org/10.1348/096317903769647193

Wells, J. E., \& Peachey, J. W. (2011). Turnover intentions: Do leadership behaviors and satisfaction with the leader matter? Team Performance Management, $17(1), \quad$ 23-40. http://dx.doi.org/10.1108/13527591111114693

Yeh, H., \& Chien, S. (2012). The Mediating Effect of Organizational Commitment on Leadership Type and Job Performance. The Journal of Human Resource and Adult Learning, 8(2), 50-59.

Yiing, L. H., \& Ahmad, K. (2009). The moderating effects of organizational culture on the relationships between leadership behaviour and organizational commitment and between organizational commitment and job satisfaction and performance. Leadership \& Organization Development Journal, 30(1), 53-86. http://dx.doi.org/10.1108/01437730910927106

Yousef, D. A. (2000). Organizational commitment: A mediator of the relationships of leadership behavior with job satisfaction and performance in a non-western country. Journal of Managerial Psychology, 15(1), 6-24. http://dx.doi.org/10.1108/02683940010305270

Yukl, G. (2005). Leadership in organizations (6th ed.). Upper Saddle River, NJ.: Prentice-Hall.

\section{Copyrights}

Copyright for this article is retained by the author(s), with first publication rights granted to the journal.

This is an open-access article distributed under the terms and conditions of the Creative Commons Attribution license (http://creativecommons.org/licenses/by/3.0/). 